\title{
Expression of Egfl7 correlates with low-grade invasive lesions in human breast cancer
}

\author{
GÉRALDINE PHILIPPIN-LAURIDANT ${ }^{1-5}$, MARIE-CHRISTINE BARANZELLI ${ }^{5}$, CHANTAL SAMSON $^{1-4}$, \\ CHARLES FOURNIER ${ }^{5}$, SÉBASTIEN PINTE ${ }^{1-4}$, VIRGINIE MATTOT $^{1-4}$, \\ JACQUES BONNETERRE ${ }^{5^{*}}$ and FABRICE SONCIN ${ }^{1-4^{*}}$ \\ ${ }^{1}$ CNRS UMR8161, National Center for Scientific Research, Institute of Biology of Lille, 59021 Lille; \\ ${ }^{2}$ University Lille-Nord de France; ${ }^{3}$ Pasteur Institute of Lille; ${ }^{4}$ Ligue labellised team, \\ ${ }^{5}$ Department of General Oncology, Centre Oscar Lambret, 59020 Lille, France
}

Received November 1, 2012; Accepted December 21, 2012

DOI: $10.3892 /$ ijo.2013.1820

\begin{abstract}
Egfl7 (VE-statin) is specifically expressed by endothelial cells of normal tissues but its expression is deregulated in human cancers. Analysis of expression of Egfl7 protein and transcripts in 211 human breast cancer samples shows that Egfl 7 is strongly expressed by breast tumor cells. Egfl7 expression is significantly higher in invasive ductal than in invasive lobular carcinoma. Expression of Egfl7 transcripts is also higher in lower SBR grade lesions and in lesions which are not associated with lymph node invasion. Within the invasive ductal carcinoma sub-population, expression of Egfl7 transcripts is correlated with the SBR score and with the $\mathrm{ER}^{+}$status. High transcript and Egfl7 protein levels significantly correlate with the absence of axillary lymph node invasion. In lymph nodes, the levels of Egfl7 are correlated with the histological type of the primary lesions; they are higher in ductal than in lobular carcinoma. Egfl7 expression is thus associated with better prognosis factors and with the absence of lymph node invasion in human breast cancer lesions.
\end{abstract}

\section{Introduction}

Angiogenic factors are expressed in human breast cancer (1) and benign lesions associated with high vascular density are correlated with an increased risk of developing cancer $(2,3)$. Furthermore, breast cancer angiogenesis correlates directly with the presence of bone marrow micro-metastases (4) and with survival (5). The quantification of angiogenesis might also help to predict the possible occurrence of cancer progres-

Correspondence to: Dr Fabrice Soncin, CNRS UMR8161, National Center for Scientific Research, Institute of Biology of Lille, 1 rue du Pr Calmette, 59021 Lille, France

E-mail: fabrice.soncin@ibl.fr

*Contributed equally

Key words: angiogenesis, breast cancer, blood vessels, DCIS sion $(6,7)$ and of tumor response to treatment (reviewed in ref. 8). The egfl gene is specifically expressed by blood vessel endothelial cells during normal embryonic development and in the adult $(9,10)$. Three independent studies showed that Egfl7 expression is deregulated in human cancer: high expression levels of Egfl7 transcripts are correlated with a more advanced stage of human colon cancer and with lymph node invasion, with no correlation with overall survival or progression-free survival (11). Egfl7 is expressed by cancer cells of human hepatocarcinoma and high levels of expression are correlated with poor survival (12). In a series of human gliomas, high levels of Egfl7 in tumor tissue correlate with higher tumor grade, Ki67 index and microvascular density (13). Here, we performed the first study of the expression of Egfl7 transcripts levels and protein localization in human breast cancer lesions. As reported in other human cancers, Egfl7 is strongly expressed by breast cancer cells, in addition to blood vessel endothelial cells. However, Egfl7 expression is associated with smaller lesions and with better prognosis factors in human breast cancer, raising concerns about the Egfl7-blocking therapies currently under development.

\section{Materials and methods}

Patients and samples. Paraffin-embedded or frozen samples were obtained from 205 patients (203 women and 2 men) with 211 mammary carcinoma and for whom the definitive diagnosis was made between January 1 and July 31, 2005 following surgical resection. Detailed clinical data are provided in Table I. All tissue samples were processed and stored at the Pathology department of the Centre Oscar Lambret, Lille, France.

Antibodies. Primary goat anti-human Egfl7 antibody (AF3638 R\&D Systems), mouse anti-human Egfl7 (sc-101349, Santa Cruz Biotechnologies), goat anti-human actin (sc-1615, Santa Cruz), biotinylated rabbit anti-goat (305-066-006, Jackson Immunoreagents), peroxidase-mouse anti-goat (A9452-1VL, Sigma), and mouse anti-mouse (NA-931, GE Healthcare) antibodies were reconstituted and stored according to the manufacturer's instructions. 
Table I. Clinical characteristics of the human breast cancer samples.

\begin{tabular}{|c|c|c|c|}
\hline & All & DCIS & Invasive carcinoma \\
\hline Tumors (n) & 211 & 37 & 174 \\
\hline Patients (n) & 205 & 36 & 168 \\
\hline \multicolumn{4}{|l|}{ Gender } \\
\hline Female & 203 & 36 & 167 \\
\hline Male & 2 & 0 & 2 \\
\hline \multicolumn{4}{|l|}{ Age, years } \\
\hline Mean (SD) & $58(11)$ & $55(10)$ & $59(11)$ \\
\hline Median (min-max) & $57(39-92)$ & $54(39-75)$ & $57(39-92)$ \\
\hline \multicolumn{4}{|l|}{ Histological type } \\
\hline DCIS & $18 \%(37 / 211)$ & & $17 \%(30 / 174)$ \\
\hline Ductal & $67 \%(141 / 211)$ & & $81 \%(141 / 174)$ \\
\hline Lobular & $14 \%(30 / 211)$ & & $2 \%(3 / 174)$ \\
\hline Other & $1 \%(3 / 211)$ & & \\
\hline \multicolumn{4}{|l|}{ Tumor size, mm } \\
\hline Mean (SD) & $18(14)$ & $18(17)$ & $18(13)$ \\
\hline Median (min-max) & $15(2-100)$ & $10(2-60)$ & $15(2-100)$ \\
\hline \multicolumn{4}{|l|}{$\mathrm{T}$ from TNM } \\
\hline $\mathrm{T} 1 \mathrm{a}$ & & & $8 \%(13 / 174)$ \\
\hline $\mathrm{T} 1 \mathrm{~b}$ & & & $27 \%(47 / 174)$ \\
\hline $\mathrm{T} 1 \mathrm{c}$ & & & $40 \%(70 / 174)$ \\
\hline $\mathrm{T} 2$ & & & $23 \%(40 / 174)$ \\
\hline $\mathrm{T} 3$ & & & $2 \%(4 / 174)$ \\
\hline \multicolumn{4}{|l|}{ SBR } \\
\hline I & & & $27 \%(47 / 174)$ \\
\hline II & & & $58 \%(101 / 174)$ \\
\hline III & & & $15 \%(26 / 174)$ \\
\hline \multicolumn{4}{|l|}{ ER } \\
\hline Positive & $90 \%(182 / 203)$ & $88 \%(30 / 34)$ & $90 \%(152 / 169)$ \\
\hline \multicolumn{4}{|l|}{ PR } \\
\hline Positive & $65 \%(131 / 203)$ & $62 \%(21 / 34)$ & $66 \%(111 / 169)$ \\
\hline \multicolumn{4}{|l|}{ HER2 (IHC and FISH) } \\
\hline $0+$ & & & $42 \%(71 / 169)$ \\
\hline $3+$ & & & $6 \%(10 / 169)$ \\
\hline Undetermined & & & $3 \%(5 / 169)$ \\
\hline Positive & & & $6.5 \%(11 / 169)$ \\
\hline \multicolumn{4}{|l|}{ Emboli } \\
\hline Present & $21 \%(19 / 89)$ & 4 cases & $22 \%(19 / 85)$ \\
\hline \multicolumn{4}{|l|}{ Necrosis } \\
\hline Present & $73 \%(49 / 67)$ & $81 \%(21 / 26)$ & $68 \%(28 / 41)$ \\
\hline \multicolumn{4}{|l|}{ DCIS grade } \\
\hline 1 & $20 \%(29 / 142)$ & $16 \%(6 / 37)$ & $22 \%(23 / 105)$ \\
\hline 2 & $36 \%(51 / 142)$ & $24 \%(9 / 37)$ & $40 \%(42 / 105)$ \\
\hline 3 & $44 \%(62 / 142)$ & $60 \%(22 / 37)$ & $38 \%(40 / 105)$ \\
\hline \multicolumn{4}{|c|}{ Lobular carcinoma in situ } \\
\hline Present & - & - & $16 \%(27 / 174)$ \\
\hline \multicolumn{4}{|l|}{$\mathrm{pN}$} \\
\hline pNO & $57 \%(121 / 211)$ & $38 \%(14 / 37)$ & $61 \%(107 / 174)$ \\
\hline $\mathrm{pNOi}^{+}$and pmiN1 & $7 \%(15 / 211)$ & - & $9 \%(15 / 174)$ \\
\hline $\mathrm{pN}^{+}$ & $25 \%(49 / 211)$ & $62 \%(23 / 37)$ & $29 \%(49 / 174)$ \\
\hline
\end{tabular}


Immunohistochemistry protocol. Paraffin sections ( $4 \mu \mathrm{m})$ were processed using a Discovery (Ventana) automat, including an internal reference slide for quality control and a 'no-antibody' control slide in each batch. Slides were heated $8 \mathrm{~min}$ at $75^{\circ} \mathrm{C}$, incubated $8 \mathrm{~min}$ in EZ-PREP (Ventana), rinsed with reaction buffer (Ventana), heated $2 \mathrm{~min}$ at $37^{\circ} \mathrm{C}$ and rinsed with reaction buffer. Slides were then incubated $8 \mathrm{~min}$ at $95^{\circ} \mathrm{C}$ in $\mathrm{CC} 1$ (Ventana), $40 \mathrm{~min}$ at $100^{\circ} \mathrm{C}$ and $8 \mathrm{~min}$ at room temperature, rinsed with reaction buffer and heated $2 \mathrm{~min}$ at $37^{\circ} \mathrm{C}$, then rinsed again. Slides were then incubated $4 \mathrm{~min}$ in inhibitor D solution at room temperature, rinsed and incubated with a polyclonal anti-hEgfl7 antibody (1/30, AF3638 R\&D) diluted in Antibody Diluent (Cell Marque) for $5 \mathrm{~h}$ at room temperature. Slides were then rinsed with reaction buffer, heated for $2 \mathrm{~min}$ at $37^{\circ} \mathrm{C}$ and incubated $30 \mathrm{~min}$ at room temperature in biotinylated rabbit anti-goat antibody (1/500, Jackson ImmunoResearch), rinsed and processed for staining using the Discovery DAB Map Kit (Ventana). Slides were then rinsed and dehydrated before mounting in Vectamount Permanent Mounting Medium (Vector laboratories) and dried. Following staining, slides were analyzed twice, each time by two independent observers, including a breast pathologist (Marie-Christine Baranzelli), using an Axioplan 2 microscope (Zeiss) and compared to corresponding hematoxylin/phloxin safran-stained slides used for identification of the tumor sub-regions. Staining was analyzed on the entire tumor region of the samples and a semi-quantitative Egfl7 intensity scale was established by the observers. Immunostainings were analyzed in 5 different cell populations corresponding to infiltrating tumor cells, DCIS or lobular carcinoma tumor cells, peritumoral blood vessel endothelial cells, stromal cells and normal mammary cells surrounding the tumors. In 11 cases, the staining was also analyzed within in situ lobular carcinoma cells. The exact and approximate concordance rates of both evaluations were respectively $77 \%(121 / 158)$ and $98 \%(155 / 158, \mathrm{p}<0,001)$ The $\kappa$ concordance coefficient was 0.65 (SE 0005, p<0.0001) correcting for a $34 \%$ chance agreement. In 35 cases, the double reading resulted in a decreased estimation of the intensity of staining.

Cell culture and transfections. Primary human umbilical cord endothelial cells (HUVEC) were from Lonza and cultured according to the supplier's recommendations between passage 2 and 5. 3T3 fibroblasts (ATCC CRL-1658) were cultured in $78.5 \mathrm{~cm}^{2}$ dishes (Falcon) in Dulbecco's modified Eagle's medium (Invitrogen), 10\% calf or fetal calf serum (Hyclone), $10 \mathrm{kU} / 1$ penicillin, $10 \mathrm{mg} / 1$ streptomycin. For transient transfection, 3T3 cells were plated at 15,000 cells/ $\mathrm{cm}^{2}$ in $10 \mathrm{~cm}^{2}$ plates, grown overnight and transfected with 23 fmoles of pcDNA3-hEgfl7 expressing vector in OptiMEM (Invitrogen) and in the presence of Exgen 500 reagent $(3 \mu \mathrm{l} /$ $\mu \mathrm{g}$ DNA, Euromedex) for $6 \mathrm{~h}$ at $37^{\circ} \mathrm{C}$ in a $5 \% \mathrm{CO}_{2} / 95 \%$ air atmosphere. For RNA interference, HUVEC were plated in $4 \mathrm{~cm}^{2}$ well-plates $\left(25,000\right.$ cells $\left./ \mathrm{cm}^{2}\right)$ and transfected the next day with 60 pmoles siRNA (Dharmacon) in Primefect siRNA reagent (Lonza) mixed with EGM-2. After 24 h, EGM-2 was added and cells cultured for 24 or $48 \mathrm{~h}$. For western blot analysis, proteins were analyzed by $12 \%$ SDS-PAGE, blotted onto Immobilon-P (Millipore) and probed using the primary goat anti-human Egfl7 antibody (AF3638 R\&D Systems, 1/1,000) or a goat anti-human actin antibody (c-11, sc-1615, Santa Cruz Biotechnologies, 1/1,000) in PBS, 0.05\% Tween-20, 5\% non-fat-dry milk overnight at $4{ }^{\circ} \mathrm{C}$ under constant mixing and further incubated with an horseradish peroxidase-coupled secondary antibody (1/10,000, A9452-1VL Sigma) in PBS, $0.05 \%$ Tween-20, 5\% non-fat dry milk. Immunocomplexes were revealed using the Western Lightning-ECL kit (PerkinElmer) after exposure to Hyperfilm ECL (GE Healthcare).

Reverse-transcription quantitative PCR. Total RNA was recovered from $10-\mu \mathrm{m}$ paraffin sections using the MasterPure RNA purification kit (Epicentre Biotechnologies). Purified total RNA was treated with DNAse and retro-transcribed using the High Capacity cDNA Reverse Transcription (Life Technologies). Quantitative PCR (qPCR) was performed using a StepOne system (Applied Biosystems) and the egfl7 (Hs_00211952_m1) and $\beta 2$-microglobulin (B2M) TaqMan assays (Applied Biosystems) using the $\Delta \mathrm{C}_{\mathrm{T}}$ method with $\mathrm{B} 2 \mathrm{M}$ levels as reference. $\Delta \Delta \mathrm{C}_{\mathrm{T}}$ was calculated using one arbitrarily chosen sample set to 1 .

Statistical analyses. Comparisons of percentages were performed using the $\chi^{2}$ and Fisher's exact tests. Mean comparisons were performed using non-parametric rank Kruskall-Wallis test (for $>2$ categories) and Mann-Whitney $\mathrm{U}$ test (2 categories). Correlations were analyzed using the non-parametric Spearman correlation coefficient. The nonparametric Kaplan-Meier method was used for analysis of survival data. The search for potential prognosis factors was performed using log-rank test for categorical data and Cox model for continuous variables. Variables were considered as significant at the $\mathrm{p}=0.01$ level due to the multiplicity of tests. Reliability studies were performed using $\kappa$ statistics.

Ethics. Sample storage, handling and analysis were done according to the European regulations and the Helsinki Declaration. Patient consent and legal authorizations were obtained for all the analyses performed and for the processing of patients personal data. The protocol was approved by the 'Comité de Protection des Personnes Nord-Ouest IV' on January 12, 2010.

\section{Results}

Specificity of detection of Egfl7 in breast cancer tissues. Egfl7 transcripts and protein expression levels were evaluated in human breast cancer samples. Conditions for detecting Egfl7 by IHC were setup and the specificity of detection was assessed by staining a positive infiltrating ductal carcinoma with the antibody in the presence of a 2-fold molar excess of recombinant Egfl7 protein (14). As expected from a specific interaction, the titration of the antibody with the recombinant protein strongly reduced the signal (Fig. 1A). Furthermore, when 3T3 cells, which do not normally express significant amounts of Egfl7 (9), were transfected with a plasmid encoding the full-length human Egf17, immunoblot analysis of cell extracts using the antibody also used in IHC showed a major band at the Egfl7 expected size (30 kDa), whereas no signal was detected when using cells transfected with an empty vector (Fig. 1B). Finally, when primary human umbilical vein 


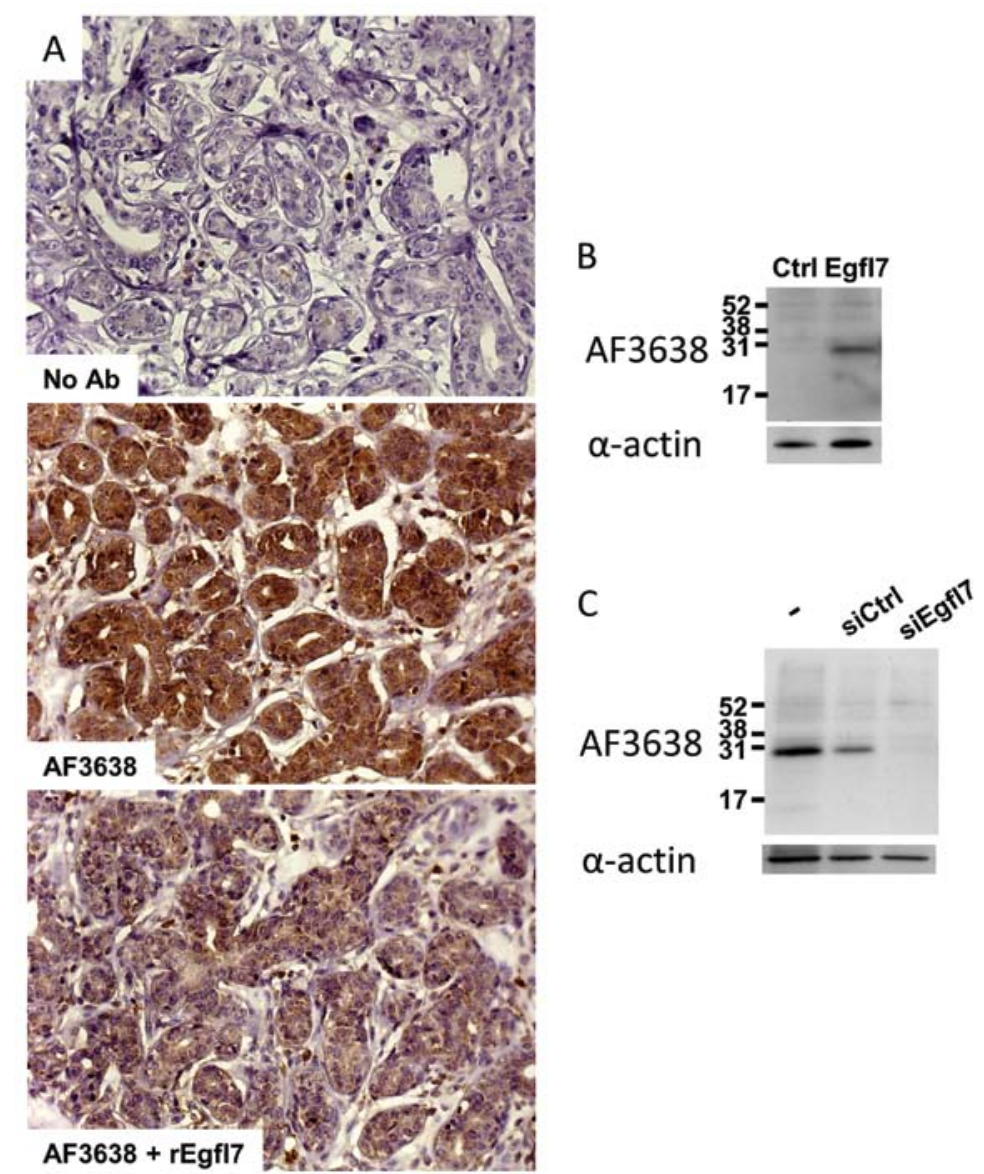

Figure 1. Specificity of the anti-Egfl7 antibody. (A) Immunohistochemistry of an infiltrating ductal carcinoma using the AF3638 antibody. No signal was observed in the absence of primary antibody (no Ab) whereas a strong staining was observed in the presence of the anti-hEgfl7 antibody (AF3638, 1/50). Competing with a 2-fold molar excess of recombinant Egfl7 strongly reduced the specific signal (AF3638+rEgfl7). (B) 3 T3 cells were transfected with a pcDNA3 plasmid (ctrl) or a pcDNA3 plasmid coding for human Egfl7. Cell extracts were processed for western blotting and analyzed using the AF3638 antibody. The antibody recognized the 29.6-kDa band corresponding to the human Egfl7 protein. (C) Western blotting of untreated HUVEC protein extract (-) or of HUVEC transfected with a control siRNA (siCtrl), or with a siRNA targeting Egfl7 (siEgfl7). The antibody recognized the endogenous Egfl7 which is constitutively produced by endothelial cells, the signal was abolished when cells were treated with the siRNA targeting egfl7, not when using the siCtrl.

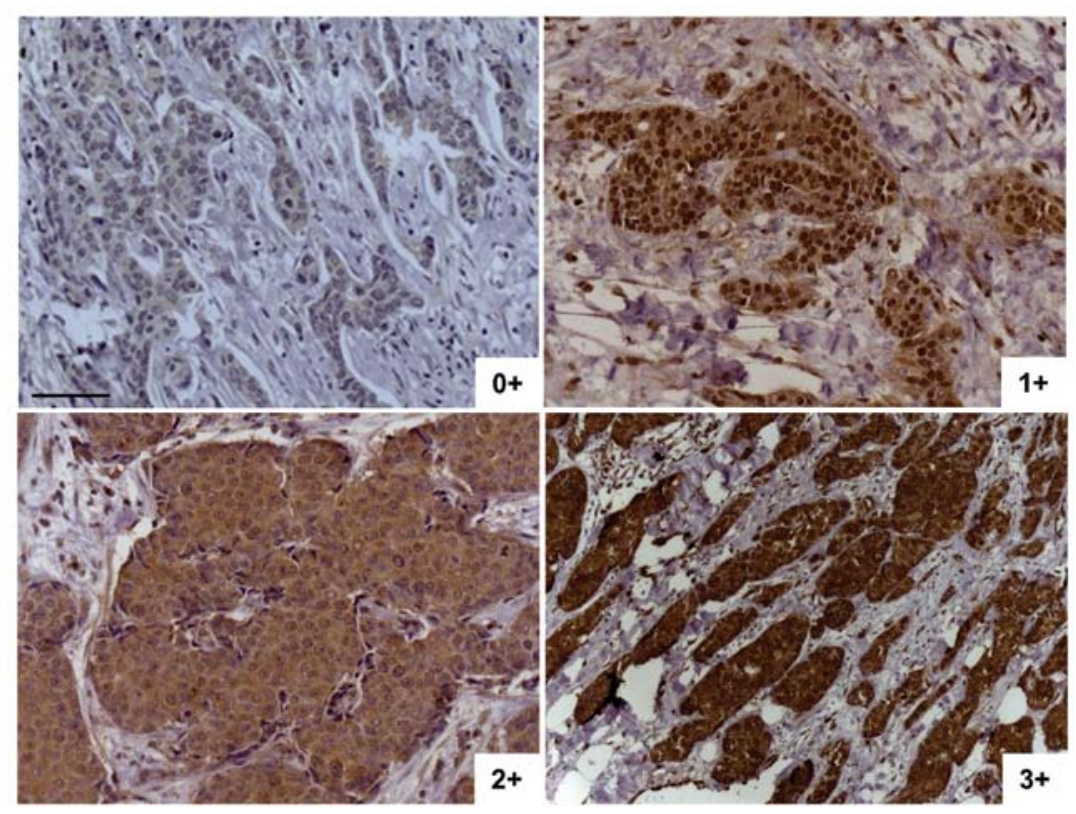

Figure 2. Egfl7 is expressed by cancer cells in breast tumor sections. Human breast tumor sections were stained using the AF3638 antibody and ranked according to the intensity of Egfl7 staining. The cytoplasmic staining was scored from 0+ when no specific staining was observed, to 3+ when the highest intensity of staining among the set of samples was observed. Note the intense, non-specific, staining in nuclei of $1+$ sample; bar, $10 \mu \mathrm{m}$. 
Table II. Egfl7 expression levels are higher in tumor cells than in normal cells.

\begin{tabular}{lcc}
\hline $\begin{array}{l}\text { Egfl7 } \\
\text { score }\end{array}$ & $\begin{array}{c}\text { Invasive tumor cells } \\
(\mathrm{n}=158)\end{array}$ & $\begin{array}{c}\text { Normal glandular cells } \\
(\mathrm{n}=111)\end{array}$ \\
\hline 0 & $29 \%(45)$ & $59 \%(65)$ \\
$1+$ & $49 \%(78)$ & $36 \%(40)$ \\
$2+$ & $18 \%(29)$ & $5 \%(6)$ \\
$3+$ & $4 \%(6)$ & $0 \%(0)$ \\
\hline
\end{tabular}

Percentage of Egfl7-positive cells in tumor cells versus normal glandular cells in invasive breast carcinoma, as assessed from IHC staining. Numbers in parenthesis indicate the number of positive cases.

endothelial cells (HUVEC), which spontaneously express high amounts of Egfl7, were treated with a siRNA specifically targeting endogenous $e g f 7$ transcripts (15), a strong decrease in protein levels was detected by immunobloting using the IHC antibody, whereas no differences were noted when using a control siRNA which does not target egfl7 (Fig. 1C). Altogether, these data indicate that the chosen antibody recognizes both the endogenous endothelial cell Egfl7 and the recombinant protein.

Expression of Egfl7 in invasive breast carcinoma. Two-hundred and eleven (211) human samples were analyzed for Egfl7 expression and localization by IHC, corresponding to 174 invasive carcinoma and 37 DCIS (Table I). Since no references were established prior to this work, a semi-quantitative scaling was established within the sample set. Slides were scored from $0+$ (no cytoplasmic staining) to 3+ (intense cytoplasmic staining, Fig. 2). In most cases, the staining was homogeneous within the same tumor. In case of heterogeneous staining within a tumor, the sample was ranked with the highest score. Invasive breast carcinoma samples were analyzed for Egfl7 protein localization by IHC. Expression of Egfl7 was significantly higher in invasive tumor cells than in normal epithelial cells ( 71 and $41 \%$ of Egfl7-positive tumors added together, respectively, $\mathrm{p}=0.003$, Table II). Furthermore, the levels of Egfl7 among the lesions analyzed were significantly higher in invasive ductal when compared to invasive lobular carcinoma (78 and $43 \%$, respectively, $p=0.001 \chi^{2}$ test, $p=0.003$ Fisher's exact test, Table III). On the other hand, no differences in protein staining were noted between $\mathrm{ER}^{+}$and ER tumors and the quantities of Egfl7 protein were not correlated with the tumor size $(\mathrm{p}=0.56)$, the patient age $(\mathrm{p}=0.45)$, the HER2 status $(\mathrm{p}=0.25)$, the presence of emboli $(\mathrm{p}=0.36)$ or with necrosis $(\mathrm{p}=0.93)$. It should also be noted that there was no specific expression profile in the triple-negative ( $\mathrm{ER}=0, \mathrm{PR}=0$, HER2 $=0)$ invasive lesions $(\mathrm{n}=8)$.

Regarding the expression levels of the Egfl7 transcripts within the same population, no differences between invasive ductal and invasive lobular carcinoma were noted (data not shown). However, the Egfl7 transcript levels were inversely correlated with the Scarf-Bloom-Richardson (SBR) score $(p=0.008$, Fig. 3A). Egfl7 transcript levels were also significantly higher in $\mathrm{ER}^{+}$tumors than in $\mathrm{ER}^{-}$tumors $(\mathrm{p}=0.002)$
Table III. Egfl7 expression levels are higher in ductal than in lobular invasive carcinoma.

\begin{tabular}{lcc}
\hline $\begin{array}{l}\text { Egfl7 } \\
\text { score }\end{array}$ & $\begin{array}{c}\text { Invasive ductal } \\
(\mathrm{n}=127)\end{array}$ & $\begin{array}{c}\text { Invasive lobular } \\
(\mathrm{n}=28)\end{array}$ \\
\hline 0 & $22 \%(28)$ & $57 \%(16)$ \\
$1+$ & $53 \%(67)$ & $36 \%(10)$ \\
$2+$ & $20 \%(26)$ & $7 \%(2)$ \\
$3+$ & $5 \%(6)$ & $0 \%(0)$ \\
\hline
\end{tabular}

Percentage of Egfl7-positive invasive ductal versus invasive lobular carcinoma, as assessed from IHC staining. Numbers in parenthesis indicate the number of positive cases.

whereas no correlations were observed when comparing the progesterone receptor status to Egfl7 expression levels (data not shown). Within the primary invasive lesions, the expression levels of Egfl7 transcripts were significantly higher in tumors which were not associated with axillary lymph node invasion $(p=0.003$, Fig. $3 \mathrm{~A})$ and the protein staining followed a similar trend ( $p=0.06$, data not shown). There were no correlations between the Egfl7 RNA levels and the size of the tumor, the age, or with the HER2 status, the presence of emboli, or with necrosis.

Interestingly, within the invasive ductal carcinoma subgroup, we confirmed that the SBR score significantly correlated with the expression levels of Egfl7 transcripts ( $\mathrm{p}=0.008$, Fig. 3B). In both instances, a higher SBR score corresponded to lower Egfl7 levels. The correlation between the ER status and Egfl7 transcript levels was also confirmed in this subpopulation, as $\mathrm{ER}^{+}$tumors expressed higher levels of Egfl7 than $\mathrm{ER}^{-}(\mathrm{p}=0.008$, Fig. 3B). Furthermore, there was a significant correlation between the expression levels of Egfl7 transcripts and the axillary lymph node invasion when analyzing this subgroup $(\mathrm{p}=0.05$ and $\mathrm{p}=0.01$, Fig. $3 \mathrm{~B}$ ), confirming the trend initially observed within the invasive carcinoma global population.

Overall, within the invasive breast carcinoma population, Egfl7 expression was preferentially observed in the invasive ductal breast carcinoma and was associated with better prognosis factors and with no lymph node invasion.

\section{Expression of Egfl7 in in situ carcinoma}

Ductal carcinoma in situ. Pure DCIS lesions (i.e., not associated with invasive carcinoma) were also analyzed by IHC, $82 \%$ of the samples were positive (score $\geq 1+$ ) for Egfl7 (Fig. 4A). Among these samples, Egfl7 staining intensities were significantly higher in tumor cells than in normal peritumoral glandular cells $(p=0.008$, Table IV). There was no significant correlation with tumor grade, but a trend to a higher frequency of samples ranked $2+$ and $3+$ when compared to $0+$ and $1+$ $(\mathrm{p}=0.07)$ was noted in this population.

In DCIS lesions associated with invasive carcinomas, the frequency of Egfl7-positive samples (score $\geq 1+$ ) was significantly higher in adjacent DCIS lesions (90\%) than in invasive tumor cells ( $71 \%, \mathrm{p}=0.001$, Table IV). Interestingly, the levels of staining were also significantly higher in smaller lesions (T1a, $\mathrm{b}$ and $\mathrm{c})$ than in $\mathrm{T} 2$ and $\mathrm{T} 3$ lesions altogether $(\mathrm{p}=0.02$, 


\section{A invasive breast carcinoma}
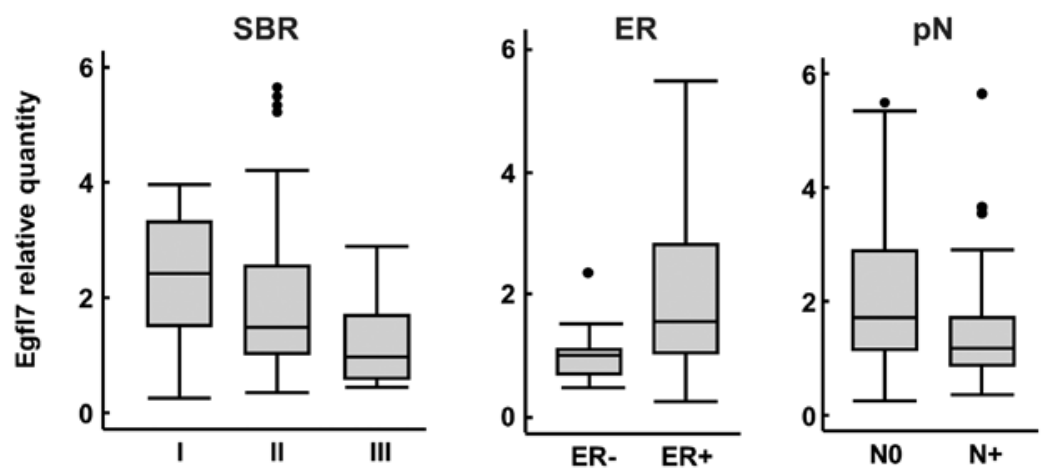

B invasive ductal carcinoma subgroup

SBR

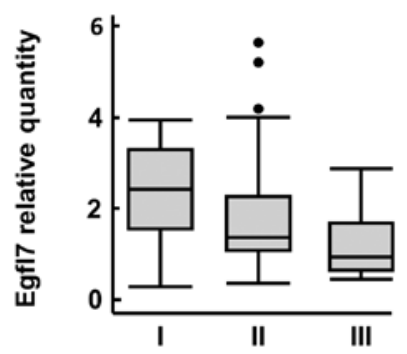

ER

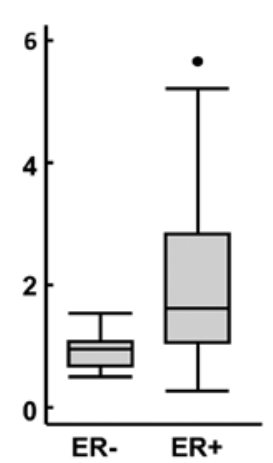

pN

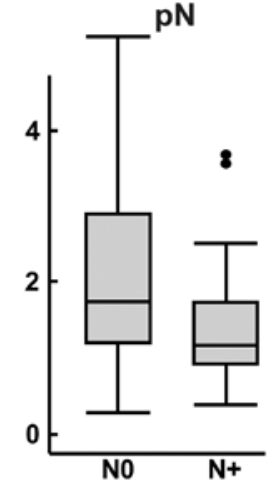

Figure 3. Egfl7 expression correlates with the SBR scores, estrogen receptors and lymph node invasion status. (A) Egfl7 transcripts levels in invasive carcinoma are inversely correlated with the SBR score $(\mathrm{p}=0.008$, left), they are positively correlated with the estrogen receptor status ( $\mathrm{p}=0.002$, middle) and inversely correlated with the lymph node invasion status $(\mathrm{p}=0.006$, right). (B) These results were observed also within the invasive ductal carcinoma subgroup.

Table IV. Comparison of expression of Egfl7 in pure DCIS and in DCIS associated with invasive lesions.

\begin{tabular}{|c|c|c|c|c|}
\hline \multirow[b]{2}{*}{$\begin{array}{l}\text { Egfl7 } \\
\text { score }\end{array}$} & \multicolumn{2}{|c|}{ Pure DCIS } & \multicolumn{2}{|c|}{$\begin{array}{c}\text { DCIS associated } \\
\text { with invasive lesions }\end{array}$} \\
\hline & $\begin{array}{l}\text { Tumor } \\
\text { cells } \\
(n=34)\end{array}$ & $\begin{array}{c}\text { Normal } \\
\text { glandular cells } \\
\quad(n=31)\end{array}$ & $\begin{array}{c}\text { Invasive } \\
\text { tumor cells } \\
(n=158)\end{array}$ & $\begin{array}{c}\text { DCIS tumor } \\
\text { cells } \\
(n=79)\end{array}$ \\
\hline $0+$ & $18 \% \quad(6)$ & $48 \%(15)$ & $29 \%(45)$ & $10 \% \quad(8)$ \\
\hline $1+$ & $26 \% \quad(9)$ & $52 \%(16)$ & $49 \%(78)$ & $49 \%(39)$ \\
\hline $2+$ & $32 \%(11)$ & $0 \% \quad(0)$ & $18 \%(29)$ & $34 \%(27)$ \\
\hline $3+$ & $24 \% \quad(8)$ & $0 \% \quad(0)$ & $4 \% \quad(6)$ & $6 \% \quad(5)$ \\
\hline
\end{tabular}

Left columns, percentage of Egfl7-positive cases in pure DCIS lesions. Expression of Egfl7 is significantly higher in tumor cells than in adjacent normal cells. Right columns, percentage of Egfl7-positive cases in DCIS associated with invasive lesions. Expression of Egfl7 is significantly higher in DCIS when compared to invasive tumor cells. Numbers in parenthesis indicate the number of positive cases. Data in italics are duplicated from Table II for sake of clarity.

Table V), showing again that Egfl7 expression is associated with smaller lesions in breast cancer patients.

When comparing pure DCIS with DCIS lesions associated with invasive carcinoma, the number of $3+$ lesions was
Table V. Percentage of Egfl7-positive cases in DCIS lesions associated with invasive carcinoma, comparison of the Tn score to that of Egfl7.

\begin{tabular}{|c|c|c|c|c|}
\hline & \multicolumn{4}{|c|}{ Egfl7 score } \\
\hline & 0 & $1+$ & $2+$ & $3+$ \\
\hline $\mathrm{T} 1 \mathrm{a}+\mathrm{T} 1 \mathrm{~b}+\mathrm{T} 1 \mathrm{c}(\mathrm{n}=64)$ & $5 \%(3)$ & $52 \%(33)$ & $36 \%(23)$ & $8 \%(5)$ \\
\hline $\mathrm{T} 2+\mathrm{T} 3(\mathrm{n}=15)$ & $33 \%(5)$ & $40 \% \quad(6)$ & $27 \% \quad(4)$ & $0 \%(0)$ \\
\hline
\end{tabular}

Numbers in parenthesis indicate the number of positive cases.

significantly higher in pure DCIS lesions than within DCIS lesions associated with infiltrating carcinoma (23 and 6\%, respectively, $\mathrm{p}=0.009 \chi^{2}$ test, $\mathrm{p}=0.02$ Fisher's exact test). Similarly, the expression levels of Egfl7 transcripts were significantly higher in pure DCIS lesions than all other lesions taken together ( $\mathrm{p}=0.0008$, Fig. 4B).

Lobular carcinoma in situ. Lobular carcinoma in situ were associated with lobular invasive carcinoma in 11 cases. Staining for Egfl7 was essentially cytoplasmic, noted as $0+$ in $27 \%$ of the cases, $1+$ in $64 \%$ of the cases, $2+$ in $9 \%$ of the cases (data not shown). No $3+$ lesions were observed and no statistical analyses were performed on this small sample population. 

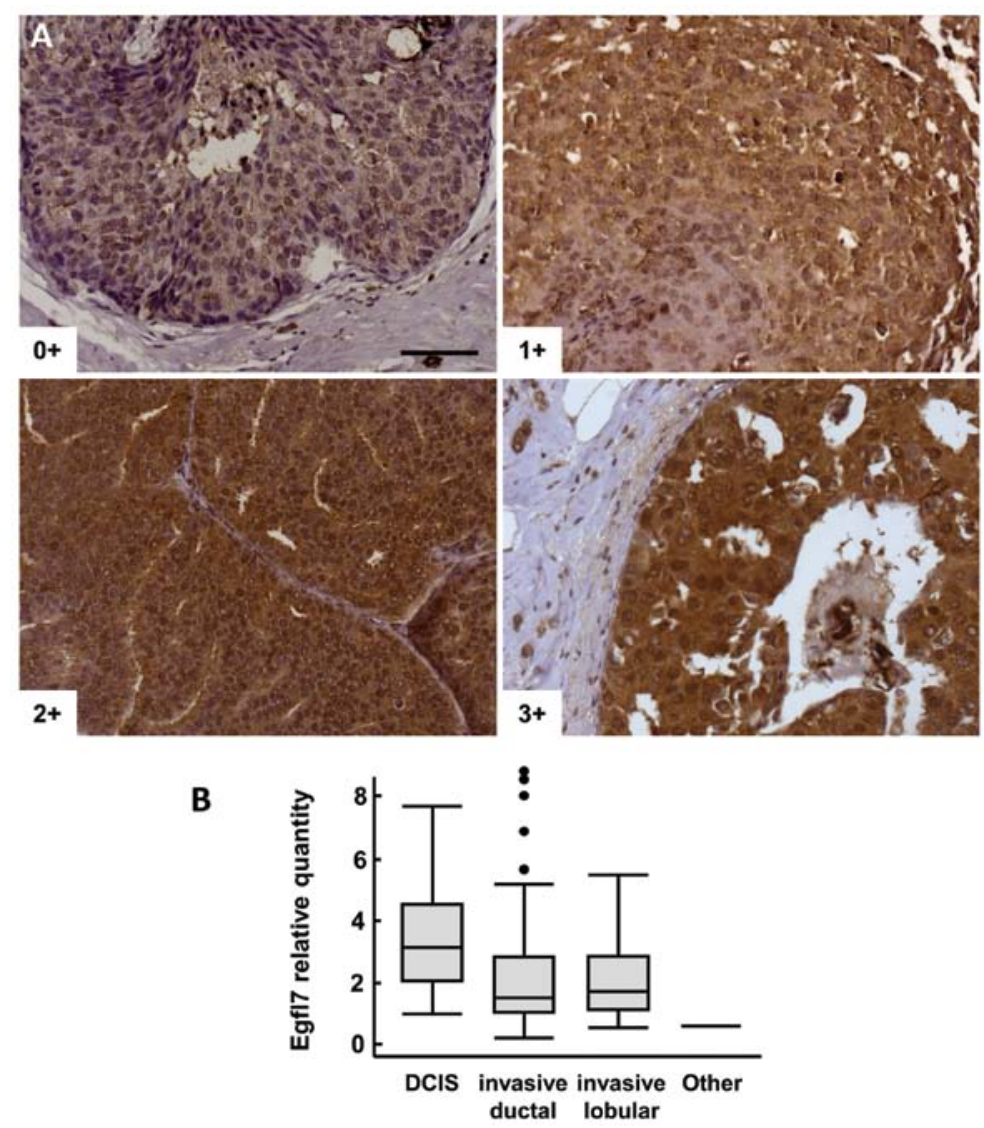

Figure 4. Egfl7 expression in pure DCIS lesions. (A) Expression of Egfl7 was analysed by immunohistochemistry in pure DCIS lesions (i.e., not associated with invasive carcinoma) and scored according to Fig. 2; bar, $10 \mu \mathrm{m}$. (B) Expression levels of Egfl7 transcripts as measured by RT-qPCR were significantly higher in pure DCIS lesions than all other lesions taken together $(\mathrm{p}=0.0008)$.

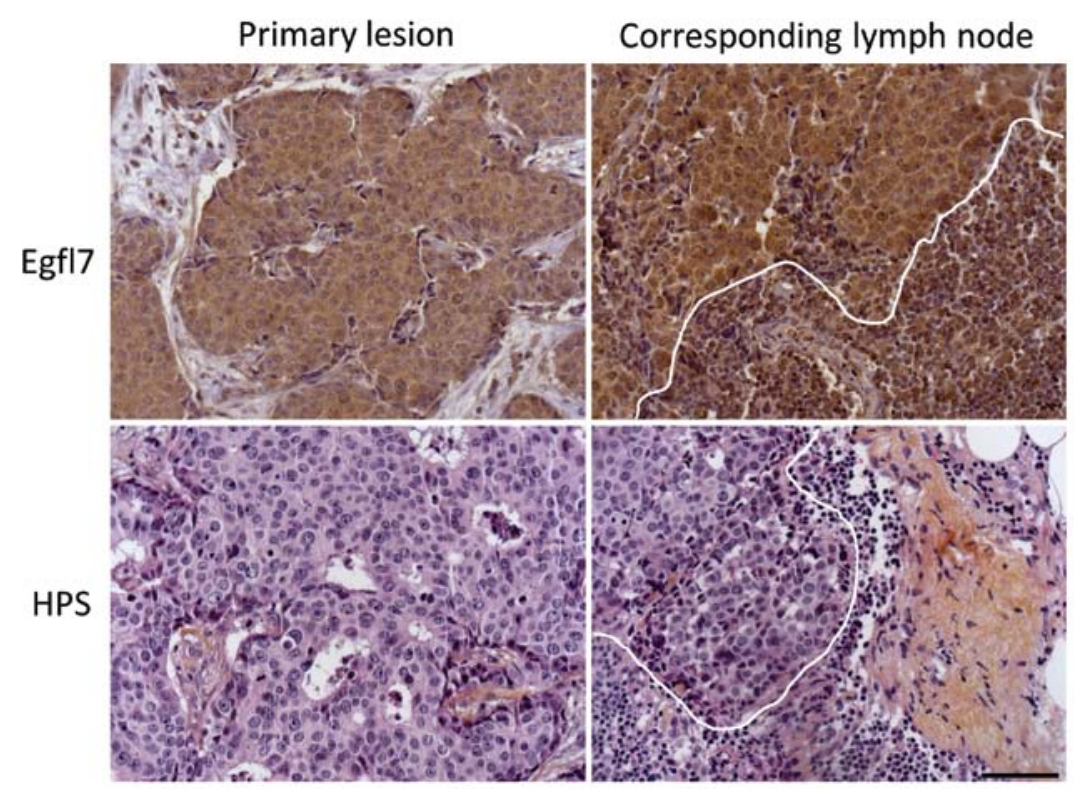

Figure 5. Expression of Egfl7 in lymph node metastases matches that of the primary lesions. Expression of Egfl7 in a primary lesion (top left) and corresponding lymph node (top right) was assessed using IHC and scored according to Fig. 2. Bottom, hematoxylin/phloxin safran (HPS) staining of corresponding sections, bar, $10 \mu \mathrm{m}$.

Expression of Egfl in axillary lymph node metastasis. The lymph nodes of 171 patients diagnosed with invasive lesions were available, among which no node invasion was noted in
$61 \%$ of the cases ( $n=107, \mathrm{pN} 0)$. In $9 \%$ of the cases, isolated cancer cells or micrometastasis were too small to be analyzed. Egfl7 protein expression and localization was thus evaluated 
Table VI. Percentage of Egfl7-positive cases in invaded lymph nodes scored according to Egfl7 expression.

\section{Egfl7 score $(n=33)$}

\begin{tabular}{lr}
\hline $0+$ & $39 \%(13)$ \\
$1+$ & $36 \%(12)$ \\
$2+$ & $24 \%(8)$ \\
$3+$ & $0 \%(0)$ \\
\hline
\end{tabular}

Numbers in parenthesis indicate the number of positive cases.

by IHC in 33 invaded lymph nodes (Fig. 5 and Table VI). Again, and using univaried analysis, the quantities of Egfl7 were correlated with the histological type of the lesions, i.e., they were higher in ductal vs lobular carcinoma $(\mathrm{p}=0.01$ $\chi^{2}$ test, $p=0.02$ Fisher's exact test). On the other hand, there were no correlations with the histological SBR grade, size of the primary lesion, age, hormone receptors status, HER2, or the presence of emboli.

Expression levels of the Egfl7 transcripts were analyzed by RT-qPCR in $24 \mathrm{pN} 1$ samples. The transcript levels correlated with the size of the associated primary invasive tumor ( $p=0.02$, data not shown), including in the invasive ductal carcinoma sub-population $(\mathrm{p}=0.02)$. On the other hand, there were no correlations between the levels of expression of the Egfl7 transcripts and the age, the histological type of the primary tumor, tumor size, $\mathrm{pN}$ rank, or SBR grade, nor with progesterone receptors status, HER2 status, the presence of emboli or necrosis.

Relapse-free and overall survival. The median follow-up of the sampled population was 4.75 years ( $0-6$ years). The 2 -year relapse-free and overall survival values reached $94 \%$ (88-97\%) and $99 \%(94-100 \%)$, respectively, and the 5-year relapse-free and global survival values were $83 \%(75-89 \%)$ and $95 \%$ (89-98\%), respectively. The 2- and 5-year values of relapse-free and of overall survival in the DCIS group were $100 \%$. As may be expected from such low degrees of variation, no correlation could be measured between the levels of expression of Egfl7 and relapse-free or overall survival in the non-DCIS population when assessed by immunostaining and by RT-qPCR.

\section{Discussion}

Expression of Egfl7 in human cancer has not been extensively studied and this is the first study which addresses the expression of the protein and of its transcripts in human breast cancer. The specificity of the chosen antibody was verified using several independent approaches. Furthermore, most of the results obtained by IHC were confirmed by the analysis of the levels of Egfl7 transcripts in the same lesions using RT-qPCR, adding further strength to the IHC results.

Overall, the clinical characteristics of the sampled population corresponded to the usual epidemiological characteristics of a breast cancer population (median age 57, 80\% ductal vs. $17 \%$ lobular invasive carcinoma). However, it should be noted that a large number of small lesions was collected $(18 \mathrm{~mm}$ mean diameter, $15 \mathrm{~mm}$ median diameter for the invasive carcinoma), and that most (90\%) of the tumors were $\mathrm{ER}^{+}$while only 6.5\% were HER2-positive. This is mainly due to the specificity of our institute which recruits patients at early stages of the disease and it does not affect the statistical significance of our observations.

The main finding of this study was that Egfl7 is expressed by tumor cells and is associated with lower grade and better prognosis lesions. The fact that Egfl7 expression is deregulated in breast cancer lesions and that cancer cells show a much stronger and frequent cytoplasmic signal for Egfl7 than the surrounding tissues is consistent with previous reports in other cancers. Egfl7 protein was indeed detected in the cytoplasm of cancer cells from human hepatocarcinoma (12). On the other hand, here, higher levels of Egfl7 expression are associated with smaller and of better prognosis primary lesions as, in invasive carcinoma, Egfl7 was more highly expressed in ductal lesions, in low scored SBR lesions, and in $\mathrm{ER}^{+}$than in their respective counterparts. Similarly, in in situ carcinoma, Egfl7 was more highly expressed in smaller lesions, and in pure DCIS than in DCIS associated with infiltrating lesions. This seems apparently contradictory with the fact that Egfl7 expression was previously associated with the progression of other human cancers: in hepatocarcinoma, Egfl7 expression was correlated with the presence of multiple nodules, venous invasion and the absence of capsule. It should be however noted that Egfl7 expression was not correlated with the tumor size nor with the Edmonson-Steiner grade in these hepatic lesions (12). In colon carcinoma and in glioma, high expression levels of Egfl7 transcripts were associated with higher tumor grades $(11,13)$ and with higher microvascular density in the case of glioma (13). However, since there was no separate analysis of expression of Egfl7 in endothelial, stromal and tumor cells in these studies and since Egfl7 is highly expressed in endothelial cells, it is most probable that these correlations were at least partly due to the high vascularization of advanced tumors, as seen in gliomas (13). These analyses need to be complemented with a histologic identification, such as that performed here.

We observed that Egfl7 is more highly expressed in ductal carcinoma than in lobular carcinoma. Ductal and lobular carcinoma have distinct biological characteristics, such as E-cadherin expression (16), cellular cohesion, different metastasis targets, and blood vessel formation (17) which may account for these differences. It should also be noted that Egfl7 expression is associated with lower grade SBR tumors, which are themselves associated with $\mathrm{ER}^{+}$lesions, whereas the incidence of $\mathrm{ER}^{+}$lesions is higher in lobular invasive carcinoma than ductal carcinoma. This suggests that Egfl7 expression is regulated by mechanisms independent from that regulating estrogen receptor expression in breast cancer.

Although Egfl7 expression was associated with lower grade lesions and better prognosis, it showed no correlation with survival rates. This is most certainly due to the size of the population tested which, when associated with high survival rates, could not allow a meaningful statistical analysis. It should be noted that a similar absence of correlation between Egfl7 transcript expression and survival was also observed in colon carcinoma (11), whereas a positive correlation was found in a study performed in hepatocarcinoma, although this study was performed on a very limited number of cases (12). 
Egfl7 expression in human cancer needs to be carefully analyzed as Egfl7 may play complex roles in cancer biology. Indeed, Egfl7 has different effects on tumor cells depending on their origin: Egfl7 increases tumor cell migration of hepatocarcinoma cells (12) while it has no effects on breast cancer cell migration (18). Here, we found that Egfl7 is not associated with a more advanced disease when expressed by human breast cancer epithelial cells. Thus, it probably does not provide per se a growth advantage to cancer cells which express it. This is consistent with the observations that Egfl7 is not an oncogene as it does not increase breast tumor cell proliferation, migration, nor clone formation (18). The molecular targets of Egfl7 and its functions are not well characterized. We have previously shown that Egfl7 inhibits the activity of the extracellular lysyl oxidases, thus preventing elastogenesis within the vascular walls (15). Egfl7 was also shown to inhibit the Notch signaling by a direct interaction with the Notch family of receptors (19). Interestingly, the Notch receptors seem to play opposite roles in human breast cancer as Notch-1 seems to promote cancer while Notch-2 correlates with a better outcome (20). Expression of the Notch ligand Jag1 is also associated with poor outcome in human breast cancer (21). Whether Egfl7 interacts with Notch receptors during the development of breast cancer and whether this interaction might be important for the progression of the disease is not known at present.

Based on this study, it seems that Egfl7 is not expressed similarly in different human cancers, raising specific concerns regarding the planned therapies which target Egfl7 in order to treat cancer.

\section{Acknowledgements}

We would like to acknowledge the help of Ms. Delphine Bertin, Dr Xavier Leroy and Dr Yves Marie-Robin. We are grateful to the Cancéropole Nord-Ouest Tumorothèque. This study was supported by Ligue Nationale contre le Cancer (Equipe Labellisée La Ligue to F.S.), Institut National du Cancer (no. 2008-053 to F.S.) and Association pour la Recherche sur le Cancer (to F.S.). G.L.P. was supported by a fellowship 'Année Recherche' from Ministère de l'Enseignement Supérieur et de la Recherche. F.S. is Directeur de Recherche of the Institut National de la Santé et de la Recherche Médicale.

\section{References}

1. Relf M, LeJeune S, Scott PA, Fox S, Smith K, Leek R, Moghaddam A, Whitehouse R, Bicknell R and Harris AL: Expression of the angiogenic factors vascular endothelial cell growth factor, acidic and basic fibroblast growth factor, tumor growth factor beta-1, platelet-derived endothelial cell growth factor, placenta growth factor, and pleiotrophin in human primary breast cancer and its relation to angiogenesis. Cancer Res 57: 963-969, 1997.

2. Weidner N, Semple JP, Welch WR and Folkman J: Tumor angiogenesis and metastasis--correlation in invasive breast carcinoma. N Engl J Med 324: 1-8, 1991.
3. Weidner N, Folkman J, Pozza F, Bevilacqua P, Allred EN, Moore DH, Meli S and Gasparini G: Tumor angiogenesis: a new significant and independent prognostic indicator in early-stage breast carcinoma. J Natl Cancer Inst 84: 1875-1887, 1992.

4. Fox SB, Leek RD, Bliss J, Mansi JL, Gusterson B, Gatter KC and Harris AL: Association of tumor angiogenesis with bone marrow micrometastases in breast cancer patients. J Natl Cancer Inst 89: 1044-1049, 1997.

5. Uzzan B, Nicolas P, Cucherat M and Perret GY: Microvessel density as a prognostic factor in women with breast cancer: a systematic review of the literature and meta-analysis. Cancer Res 64: 2941-2955, 2004.

6. Guidi AJ, Fischer L, Harris JR and Schnitt SJ: Microvessel density and distribution in ductal carcinoma in situ of the breast. J Natl Cancer Inst 86: 614-619, 1994.

7. Engels K, Fox SB, Whitehouse RM, Gatter KC and Harris AL: Distinct angiogenic patterns are associated with high-grade in situ ductal carcinomas of the breast. J Pathol 181: 207-212, 1997.

8. Fox SB, Generali DG and Harris AL: Breast tumour angiogenesis. Breast Cancer Res 9: 216, 2007.

9. Soncin F, Mattot V, Lionneton F, Spruyt N, Lepretre F, Begue A and Stehelin D: VE-statin, an endothelial repressor of smooth muscle cell migration. EMBO J 22: 5700-5711, 2003.

10. Parker LH, Schmidt M, Jin SW, Gray AM, Beis D, Pham T, Frantz G, Palmieri S, Hillan K, Stainier DY, De Sauvage FJ and Ye W: The endothelial-cell-derived secreted factor Egfl7 regulates vascular tube formation. Nature 428: 754-758, 2004.

11. Diaz R, Silva J, Garcia JM, Lorenzo Y, Garcia V, Pena C, Rodriguez R, Munoz C, Garcia F and Bonilla F and Dominguez G: Deregulated expression of miR-106a predicts survival in human colon cancer patients. Genes Chromosomes Cancer 47: 794-802, 2008.

12. Wu F, Yang LY, Li YF, Ou DP, Chen DP and Fan C: Novel role for epidermal growth factor-like domain 7 in metastasis of human hepatocellular carcinoma. Hepatology 50: 1839-1850, 2009.

13. Huang $\mathrm{CH}, \mathrm{Li} \mathrm{XJ}$, Zhou YZ, Luo Y, Li C and Yuan XR: Expression and clinical significance of EGFL7 in malignant glioma. J Cancer Res Clin Oncol 136: 1737-1743, 2010.

14. Caetano B, Drobecq H and Soncin F: Expression and purification of recombinant vascular endothelial-statin. Protein Expr Purif 46: 136-142, 2006.

15. Lelièvre E, Hinek A, Lupu F, Buquet C, Soncin F and Mattot V: VE-statin/egfl7 regulates vascular elastogenesis by interacting with lysyl oxidases. EMBO J 27: 1658-1670, 2008.

16. Moll R, Mitze M, Frixen UH and Birchmeier W: Differential loss of E-cadherin expression in infiltrating ductal and lobular breast carcinomas. Am J Pathol 143: 1731-1742, 1993.

17. Lee AH, Dublin EA, Bobrow LG and Poulsom R: Invasive lobular and invasive ductal carcinoma of the breast show distinct patterns of vascular endothelial growth factor expression and angiogenesis. J Pathol 185: 394-401, 1998.

18. Delfortrie S, Pinte S, Mattot V, Samson C, Villain G, Caetano B, Lauridant-Philippin G, Baranzelli M-C, Bonneterre J, Trottein F, Faveeuw $\mathrm{C}$ and Soncin F: Egfl7 promotes tumor escape from immunity by repressing endothelial cell activation. Cancer Res 71: 7176-7186, 2011

19. Schmidt MH, Bicker F, Nikolic I, Meister J, Babuke T, Picuric S, Muller-Esterl W, Plate KH and Dikic I: Epidermal growth factorlike domain 7 (EGFL7) modulates Notch signalling and affects neural stem cell renewal. Nat Cell Biol 11: 873-880, 2009.

20. Parr C, Watkins G and Jiang WG: The possible correlation of Notch-1 and Notch-2 with clinical outcome and tumour clinicopathological parameters in human breast cancer. Int J Mol Med 14: 779-786, 2004.

21. Dickson BC, Mulligan AM, Zhang H, Lockwood G, O'Malley FP, Egan SE and Reedijk M: High-level JAG1 mRNA and protein predict poor outcome in breast cancer. Mod Pathol 20: 685-693, 2007. 